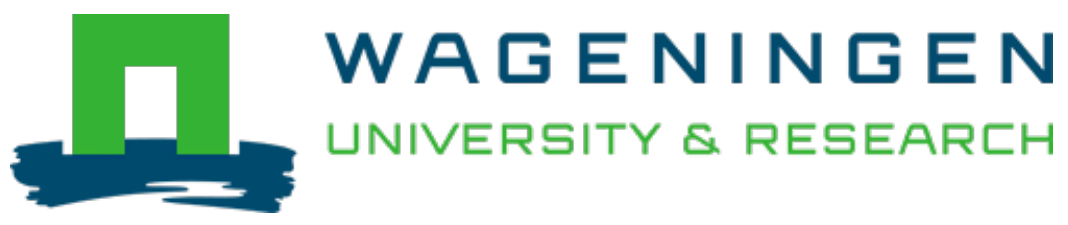

\title{
Microbiological safety and quality of commercial sufu - a Chinese fermented soybean food
}

\section{Food Control}

Han, B.Z.; Beumer, R.R.; Rombouts, F.M.; Nout, M.J.R.

https://doi.org/10.1016/S0956-7135(01)00064-0

This publication is made publicly available in the institutional repository of Wageningen University and Research, under the terms of article $25 \mathrm{fa}$ of the Dutch Copyright Act, also known as the Amendment Taverne. This has been done with explicit consent by the author.

Article 25 fa states that the author of a short scientific work funded either wholly or partially by Dutch public funds is entitled to make that work publicly available for no consideration following a reasonable period of time after the work was first published, provided that clear reference is made to the source of the first publication of the work.

This publication is distributed under The Association of Universities in the Netherlands (VSNU) 'Article $25 \mathrm{fa}$ implementation' project. In this project research outputs of researchers employed by Dutch Universities that comply with the legal requirements of Article $25 \mathrm{fa}$ of the Dutch Copyright Act are distributed online and free of cost or other barriers in institutional repositories. Research outputs are distributed six months after their first online publication in the original published version and with proper attribution to the source of the original publication.

You are permitted to download and use the publication for personal purposes. All rights remain with the author(s) and / or copyright owner(s) of this work. Any use of the publication or parts of it other than authorised under article $25 \mathrm{fa}$ of the Dutch Copyright act is prohibited. Wageningen University \& Research and the author(s) of this publication shall not be held responsible or liable for any damages resulting from your (re)use of this publication.

For questions regarding the public availability of this publication please contact openscience.library@wur.nl 


\title{
FOOD CONTROL
}

\section{Microbiological safety and quality of commercial sufu - a Chinese fermented soybean food}

\author{
Bei-Zhong Han ${ }^{\text {a,b }}$, Rijkelt R. Beumer ${ }^{\text {a }}$, Frans M. Rombouts ${ }^{\text {a }}$, M.J. Robert Nout ${ }^{\text {a,* }}$ \\ ${ }^{a}$ Laboratory of Food Microbiology, Department of Agrotechnology and Food Sciences, Wageningen University, \\ P.O. Box 8129, 6700 EV Wageningen, The Netherlands \\ ${ }^{\mathrm{b}}$ College of Food Science and Engineering, China Agricultural University, Beijing 100083, China \\ Received 21 April 2001; received in revised form 26 June 2001; accepted 29 June 2001
}

\begin{abstract}
In this study, the microbiological safety and quality of commercial sufu were investigated. Twenty-three samples of three different types of sufu were obtained, mainly in China and some in The Netherlands. Chemical parameters analysed included moisture, $\mathrm{pH}$, free amino $\mathrm{N}, \mathrm{NaCl}$, ethanol, sucrose, glucose, and fructose. Concentrations of $\mathrm{NaCl}$, ethanol, glucose and fructose varied from $6.2 \%, 0.5 \%, 0 \%$ and $0 \%$ to $14.8 \%, 6.3 \%, 6.2 \%$ and $4.8 \%$, respectively. Microbiological analyses were done for total count of mesophilic aerobic bacteria (TMAB), bacterial endospores, total count of halotolerant bacteria at $10 \%$ (THB10) and at $17.5 \% \mathrm{NaCl}$ (THB17.5), lactic acid bacteria (LAB), fungi, Enterobacteriaceae, and the following pathogens: Bacillus cereus, Clostridium perfringens, Staphylococcus aureus and Listeria monocytogenes. High levels ( $\left.>10^{5} \mathrm{CFU} / \mathrm{g}\right)$ of TMAB and bacterial endospores were found in most samples, and $85 \%$ of TMAB was identified as Gram-positive. Considerable levels $\left(10^{5}\right.$ and $\left.10^{7} \mathrm{CFU} / \mathrm{g}\right)$ of LAB were detected in two samples of white sufu, and isolates of LAB were identified as most probably $L b$. casei. One-third of the samples contained less then $10^{3} \mathrm{CFU} / \mathrm{g} \mathrm{B}$. cereus, but three samples had over $10^{5} \mathrm{CFU} / \mathrm{g}$ indicating potential hazard to consumers. All samples had less than $10^{3} \mathrm{CFU} / \mathrm{g} C$. perfringens, except sample R11 ( $\left.\sim 10^{5} \mathrm{CFU} / \mathrm{g}\right)$. S. aureus could not be detected in any of the samples tested since the competitive microflora (usually bacilli) disturbed typical features on the selective medium used; however $S$. aureus enterotoxin A was detected in some of the white and grey sufu samples. Fungi, Enterobacteriaceae, and L. monocytogenes were not detected in any of the samples. Based on these results, a microbiological guideline for safe commercial sufu is proposed. (C) 2001 Elsevier Science Ltd. All rights reserved.
\end{abstract}

Keywords: Sufu; Fermented soybean food; Microbiological safety

\section{Introduction}

Sufu or furu is a traditional Chinese fermented soybean curd resembling a soft creamy cheese-type product, which can be used in a similar way as cheese (Steinkraus, 1996). It has been one of the most popular highly flavoured side dishes consumed in China for many centuries, and is becoming popular in Chinese shops all over the world.

Sufu is produced by various processes in different localities of China (Wang \& Du, 1998). Four steps are usually involved in making sufu: (1) preparing tofu by salt precipitation from boiled soymilk, (2) preparing pehtze (pizi) by spray-inoculation of diced tofu with a

\footnotetext{
${ }^{*}$ Corresponding author. Tel.: +31-317-482834; fax: +31-317484978.

E-mail address: rob.nout@micro.fdsci.wau.nl(M.J. Robert Nout).
}

pure culture fermentation starter, (3) salting, and (4) ripening in a dressing mixture. The sufu process and variations in recipes and compositions were described by Wang and Hesseltine (1970), Su (1986), and Han, Rombouts, and Nout (2001). The pure culture starters mainly consist of moulds - Mucoraceae (Actinomucor, Mucor and Rhizopus) or bacteria - Micrococcus and Bacillus spp. Although a pure culture is used in the pehtze fermentation, the process of sufu manufacture itself is carried out under non-sterile conditions, and by consequence microbial contamination will occur.

Whereas most sufu contains considerable levels of the antimicrobial $\mathrm{NaCl}(5-15 \%)$ and ethanol $(1-7 \%)$ that could prevent the survival or growth of pathogens, it is also known that the endospore-forming rods such as Bacillus spp. and Clostridium spp. vary greatly in their salt tolerance (Brewer, 2000). The fact that several bacteria have a remarkable ability to survive different 
environmental stress conditions makes it very difficult for the food industry to exclude them from their products (Andersson, Rönner, \& Granum, 1995).

Earlier investigations of fermented soybean foods, e.g., tempe and kinema, revealed the presence of considerable levels of food-borne pathogenic bacteria such as Bacillus cereus, Staphylococcus aureus and Enterobacteriaceae (Nout, Bakshi, \& Sarkar, 1998; Samson, Van Kooij, \& De Boer, 1987). Tofu is the precursor of sufu. Food-borne pathogenic bacteria, such as Enterobacteriaceae, B. cereus and $S$. aureus were found in commercial tofu (Ashraf, White, \& Klubek, 1999; Rehberger, Wilson, \& Glatz, 1984; Van Kooij \& De Boer, 1985). But to date, there is only scant information about the microbiological safety and quality of sufu (Pao, 1989).

From the microbiological public health point of view, it is of interest to investigate the microorganisms present in commercial products, with special reference to foodborne pathogenic bacteria. The data obtained from this study can be useful in developing and proposing microbiological guidelines for the commercial production of high quality sufu products.

\section{Materials and methods}

\subsection{Collection of samples}

Twenty-three samples of sufu were obtained from different markets and factories in China and The Netherlands. Their origins of production were Beijing (capital of China), Heilongjiang (North-east of China), Jiangsu (East), Shanxi (West), Sichuan (South-west), Guangdong (South), Guangxi (South), Hong Kong (South), Taiwan (South-east) and Fujiang (South-east). According to their colour and flavour, they were classified into three types (red, white and grey sufu) which are mainly based on the different ingredients of dressing mixture during the ripening phase (Han et al., 2001), which can be regarded as representative of the major types of sufu in China. All samples were stored at room temperature as is usual in sufu retail shops.

\subsection{Chemical analysis}

\subsubsection{Moisture}

Moisture content was determined by conventional oven-drying $\left(80^{\circ} \mathrm{C}, 48 \mathrm{~h}\right)$ of $10 \mathrm{~g}$ sufu.

\subsection{2. $\mathrm{pH}$ and free amino nitrogen}

A sufu sample $(2 \mathrm{~g})$ was homogenised with $18 \mathrm{ml}$ demineralised water. The $\mathrm{pH}$ was measured in this suspension using a digital pH meter (WTW, type 525, Weilheim, Germany). While stirring continuously and working in a fume hood, $0.1 \mathrm{M} \mathrm{NaOH}$ was added to the suspension to a constant $\mathrm{pH} 8.5$, followed by addition of $5 \mathrm{ml}$ formaldehyde (37\%; Code no. 1.04003.1000, Merck, Germany). After 2 min the suspension was titrated by semi- automated burette (Schott-Gerate, type T81; Hofheim a. Ts. Germany) with $0.100 \mathrm{M} \mathrm{NaOH}$ to constant $\mathrm{pH} 8.5$ again ( $\mathrm{pH}$ should be constant for $30 \mathrm{~s}$ ). Free amino nitrogen $(\mathrm{mM} / \mathrm{g})$ was calculated as $0.1 * V / m$; where $V$ is the volume of $0.100 \mathrm{M} \mathrm{NaOH}$ used, and $m$ is the sample fresh weight. Chemical waste was disposed off as toxic waste.

\subsubsection{Salt concentration}

A sufu sample $(2 \mathrm{~g})$ was homogenised with $18 \mathrm{ml}$ demineralised water. This 10 -fold diluted sufu was titrated with $0.1 \mathrm{M} \mathrm{AgNO}_{3}$, and $10 \% \mathrm{w} / \mathrm{v} \mathrm{K}_{2} \mathrm{CrO}_{4}$ solution was used as an indicator. The following equation was used: $\%$ Salt as $\%$ (w/w) $\mathrm{NaCl}=V * M * 0.0584 *$ $100 / m$; where $V$ and $M$ are the volume and molarity of $\mathrm{AgNO}_{3}$ used, and $m$ is the mass of a fresh sample.

\subsubsection{Ethanol, sucrose, glucose and fructose concentra- tion}

The determination of ethanol, sucrose, glucose and fructose content was performed on a HPLC isocratic RI analyser, column: Aminex HPX-87H $(300 * 7.8 \mathrm{~mm})$; sample: $20 \mu \mathrm{l}$; eluant: $5 \mathrm{mM} \mathrm{H}_{2} \mathrm{SO}_{4}$; flow rate: $0.6 \mathrm{ml} /$ min; temperature: $40{ }^{\circ} \mathrm{C}$. Sufu sample dilutions as mentioned above were deproteinised using Carrez reagents, a mixture of $\mathrm{ZnSO}_{4} \cdot 7 \mathrm{H}_{2} \mathrm{O}$ and $\mathrm{K}_{4} \mathrm{Fe}(\mathrm{CN})_{6}$. $3 \mathrm{H}_{2} \mathrm{O}$ according to White (1979), before injection into the analyser.

\subsection{Subsampling and sample treatment for microbiolog- ical analysis}

Representative $20 \mathrm{~g}$ portions were aseptically weighed, mixed with $180 \mathrm{ml}$ peptone saline $(0.1 \%$ neutral peptone, $2.5 \% \mathrm{NaCl}$ ) with higher than physiological salt concentration to minimise osmotic shock, and homogenised by blending for $30 \mathrm{~s}$ at high speed in a Laboratory Blender (Stomacher 400, England). Subsequent decimal dilutions were prepared with the same diluent, and in all cases, duplicate counting plates were prepared of appropriate dilutions.

\subsection{Microbiological analysis}

\subsubsection{Total count of mesophilic aerobic bacteria (TMAB)}

TMAB was enumerated in pour-plates of plate count agar (PCA, CM325, Oxoid, England) to which $25 \mathrm{~g}$ $\mathrm{NaCl}$ was added per litre, after incubation at $30{ }^{\circ} \mathrm{C}$ for 2-3 d. 
2.4.2. Total count of halotolerant bacteria (THB10) with $10 \%$ and (THB17.5) with $17.5 \%$ salt concentration

THB10 and THB17.5 were enumerated in pour-plates of PCA to which 100 and $175 \mathrm{~g} \mathrm{NaCl}$ were added per litre, after incubation at $30{ }^{\circ} \mathrm{C}$ for 7 and $14 \mathrm{~d}$, respectively.

\subsubsection{Bacterial endospores}

Sufu samples were pasteurised $\left(80{ }^{\circ} \mathrm{C}, 10 \mathrm{~min}\right)$ and bacterial endospores were enumerated in pour-plates of PCA to which $25 \mathrm{~g} \mathrm{NaCl}$ was added per litre, after incubation at $30{ }^{\circ} \mathrm{C}$ for $2-3 \mathrm{~d}$.

\subsubsection{Lactic acid bacteria}

Lactic acid bacteria (LAB) were enumerated in pourplates of de Man, Rogosa and Sharpe medium (MRS, Cat. No. 1.10661, Merck, Germany) to which $12 \mathrm{~g}$ agar, $25 \mathrm{~g} \mathrm{NaCl}$ and $2 \mathrm{~g}$ natamycin ("Delvocid", Gist-brocades, Delft, The Netherlands) were added per litre, after incubation at $30{ }^{\circ} \mathrm{C}$ for $3-4 \mathrm{~d}$. MRS is by far a better growth medium for a wide range of LAB than, e.g., Rogosa. It needs, however, to be made selective against fungi, especially in the case of fungal fermented foods (Hounhouigan, Nout, Nago, Houben, \& Rombouts, 1993; Nout, 1991). Initial confirmation was based on Gram stain, morphology, catalase and oxidase tests. Carbohydrate metabolism of LAB isolates was determined using API $50 \mathrm{CH}$ strips and API $50 \mathrm{CHL}$ medium (bioMérieux, Lyon, France) according to the manufacturer's instructions. Tentative identification based on phenotypical properties was done with IBIS software (Intelligent Bacteria Identification System, The Netherlands) (Wijtzes, Bruggeman, Nout, \& Zwietering, 1997).

\subsubsection{Yeasts and moulds (fungi)}

Fungi were enumerated in pour-plates of standard and salt-enriched oxytetracycline glucose-yeast extract agar (OGYE, CM545, Oxoid, England) to which 0 and $25 \mathrm{~g} \mathrm{NaCl}$ was added per litre, respectively, after incubation at $30{ }^{\circ} \mathrm{C}$ for $5 \mathrm{~d}$.

\subsubsection{Bacillus cereus}

Selective enumeration was carried out on spreadplates of mannitol egg yolk polymyxin (MYP) (Cereus selective agar, Cat. No. 1.05267, Merck, Germany) to which $25 \mathrm{~g} \mathrm{NaCl}$ was added per litre. The inoculated plates were incubated at $30^{\circ} \mathrm{C}$ for $24 \mathrm{~h}$ and examined for typical colonies. Presumptive colonies (pink colonies surrounded by a zone of precipitation) were counted and subsequently transferred to a Brain Heart Infusion (BHI, No. 2337500, DIFCO, France) agar with added fresh sheep blood (50-70 ml/1 BHI) (sheep blood defibrinated, bio TRADING benelux, The Netherlands) for confirmation, as specified in ISO method (ISO/DIS 7932, 1993). Carbohydrate metabolism by isolates of bacilli was determined using API $50 \mathrm{CH}$ strips and API
50 CHB medium (bioMérieux, Lyon, France) according to the manufacturer's instructions. The resulting biochemical profiles were interpreted using APILAB software (Version 3.3.3, 1990, bioMérieux, Lyon, France).

\subsubsection{Clostridium perfringens}

Selective enumeration was carried out in pour-plates of tryptose sulfite cycloserine agar (TSCA, Cat. No. 1.11972, Merck, Germany) to which $25 \mathrm{~g} \mathrm{NaCl}$ was added per litre. After incubation at $37{ }^{\circ} \mathrm{C}$ for $18-24 \mathrm{~h}$ under anaerobic conditions, black colonies were counted and subsequently confirmed according to ISO7937 (Eisgruber, Schalch, Sperner, \& Stolle, 2000) using fermentation of lactose $(+)$, gelatin liquefaction $(+)$, motility (-) and nitrate reduction $(-)$ as criteria after anaerobic incubation for $24 \mathrm{~h}$ at $37^{\circ} \mathrm{C}$.

\subsubsection{Enterobacteriaceae}

Selective enumeration was carried out in pour-plates of violet red bile glucose agar (VRBG, CM485, Oxoid, England) with overlay to which 0 and $25 \mathrm{~g} \mathrm{NaCl}$ was added, after incubation at $30{ }^{\circ} \mathrm{C}$ for $24-36 \mathrm{~h}$.

\subsubsection{Staphylococcus aureus}

Selective enumeration was carried out in pour-plates of Baird Parker agar + Rabbit plasma fibrinogen (BP+RPF, No. 44003, bioMérieux, France). After incubation at $37^{\circ} \mathrm{C}$ for $24 \mathrm{~h}, S$. aureus colonies, ringed by an opaque halo and coloured grey-black, were counted as specified in ISO method (ISO/DIS 6888-2, 1997). The detection of staphylococcal enterotoxins A, B, C, D and $\mathrm{E}$ was carried out by enzyme immunoassay (RIDASCREEN $^{\circledR}$ SET A, B, C, D, E; Art. No.: R 4101, R-Biopharm GmbH, Germany) (Park, Akhtar, \& Rayman, 1994).

\subsubsection{Listeria monocytogenes}

Diluted sample $(0.1 \mathrm{ml})$ was spread on ready-made commercial plates of Rapid'L. mono Medium (RLM, Cat. No. 63694, Sanofi, France). After 24 h of incubation at $37{ }^{\circ} \mathrm{C}$, positive control cultures of L. monocytogenes produced typical blue colonies without a yellow halo, having circular shape and smooth surface, with mean diameter of 1-2 mm (Heisick, Posas-marty, \& Tatini, 1995).

\subsection{Replications}

All samples were analysed using duplicate subsamples. Single homogenates were prepared from each subsample. On each homogenate, duplicate chemical measurements were made and reported as mean values. Microbiological data were calculated from 2-4 counting plates for each subsample and microorganism, and reported as mean values. 


\section{Results and discussion}

\subsection{Chemical parameters of commercial sufu}

Table 1 shows chemical parameters of the tested sufu samples. There was no relation between the age after manufacturing date and $\mathrm{pH}$ value, which suggests that the $\mathrm{pH}$ does not change significantly during storage. Levels of free amino nitrogen in grey sufu were higher than in red and white sufu, and this was also reflected in higher $\mathrm{pH}$ values of grey sufu.

Since there is a wide choice of methods and recipes used in the production of sufu, it was according to expectation to find a range of parameter values such as shown in Table 1. Concentrations of $\mathrm{NaCl}$, ethanol, glucose and fructose varied from $6.2 \%, 0.5 \%, 0 \%$ and $0 \%$ to $14.8 \%, 6.3 \%, 6.2 \%$ and $4.8 \%$, respectively. In addition, large variations of $\mathrm{NaCl}$, ethanol, glucose, fructose and water contents among samples from the same brand indicate that most companies do not closely control the composition of their products.
Glucose and fructose were hardly found in white and grey sufu samples except in W4 and W6, to which LaoChao (a fermented rice product) (Wang \& Hesseltine, 1970) had been added as an ingredient to the dressing mixtures. Sugar (sucrose) is commonly applied in the dressing mixture of red sufu (Han et al., 2001). However, sucrose was not found in any of the samples, suggesting that it was degraded by enzyme activities during the sufu ageing phase.

\subsection{Microbiological analysis}

High levels $\left(>10^{5} \mathrm{CFU} / \mathrm{g}\right)$ of TMAB (all samples except G3) and bacterial endospores were found (all samples except W7, W8 and G3) as shown in Table 2. The similar levels of corresponding TMAB and bacterial endospore counts found in individual samples except W7 and W8, indicate that TMAB mainly consisted of bacterial endospores. About $85 \%$ of isolates taken from TMAB counting plates were indeed Gram-positive, and mostly rod-shaped. This was to be expected, since the

Table 1

Chemical parameters of commercial sufu (fresh sample)

\begin{tabular}{|c|c|c|c|c|c|c|c|c|c|}
\hline Sample code & $\begin{array}{l}\text { Origin of } \\
\text { production }^{\text {a }}\end{array}$ & $\begin{array}{l}\text { Age } \\
\text { (month) }^{\mathrm{b}}\end{array}$ & $\begin{array}{l}\text { Moisture } \\
(\mathrm{g} / 100 \mathrm{~g})^{\mathrm{c}}\end{array}$ & $\mathrm{pH}$ & $\begin{array}{l}\text { Free amino } \\
\mathrm{N}(\mathrm{mM} / \mathrm{g})\end{array}$ & $\begin{array}{l}\mathrm{NaCl} \\
(\mathrm{g} / 100 \mathrm{~g})\end{array}$ & $\begin{array}{l}\text { Ethanol } \\
(\mathrm{g} / 100 \mathrm{~g})\end{array}$ & $\begin{array}{l}\text { Glucose } \\
(\mathrm{g} / 100 \mathrm{~g})\end{array}$ & $\begin{array}{l}\text { Fructose } \\
(\mathrm{g} / 100 \mathrm{~g})\end{array}$ \\
\hline $\mathrm{R} 1$ & $\mathrm{Be}$ & 14 & 66.3 & 6.46 & 0.29 & 9.2 & 6.2 & 4.3 & 2.0 \\
\hline $\mathrm{R} 2^{\mathrm{d}}$ & $\mathrm{Be}$ & 12 & 67.6 & 6.51 & 0.29 & 8.8 & 6.3 & 4.8 & 2.6 \\
\hline$R 3^{\mathrm{d}}$ & $\mathrm{Be}$ & 11 & 68.9 & 6.25 & 0.23 & 8.2 & 5.9 & 6.2 & 4.7 \\
\hline $\mathrm{R} 4^{\mathrm{d}}$ & $\mathrm{Be}$ & 8 & 65.1 & 6.52 & 0.28 & 10.3 & 4.8 & 4.5 & 2.6 \\
\hline R5 & $\mathrm{Be}$ & 4 & 60.5 & 6.02 & 0.24 & 9.6 & 5.5 & 5.4 & 4.8 \\
\hline $\mathrm{R} 6^{\mathrm{e}}$ & $\mathrm{Be}$ & 1 & 61.0 & 6.78 & 0.21 & 10.4 & 4.6 & 5.7 & 2.3 \\
\hline $\mathrm{R} 7^{\mathrm{e}}$ & $\mathrm{Be}$ & 6 & 63.2 & 6.20 & 0.33 & 9.6 & 4.6 & 4.0 & 1.5 \\
\hline $\mathrm{R} 8^{\mathrm{e}}$ & $\mathrm{Be}$ & 6 & 60.3 & 6.32 & 0.22 & 12.8 & 4.9 & 5.5 & 2.8 \\
\hline R9 & Sh & 6 & 58.6 & 6.30 & 0.22 & 14.8 & 5.1 & 4.1 & 2.3 \\
\hline R10 & Sh & 9 & 66.1 & 6.22 & 0.39 & 14.7 & 1.9 & 2.5 & 0.1 \\
\hline R11 & $\mathrm{Si}$ & 5 & 55.1 & 5.68 & 0.42 & 14.4 & 1.1 & 0.8 & 0.0 \\
\hline $\mathrm{R} 12$ & $\mathrm{He}$ & 6 & 56.3 & 5.50 & 0.33 & 13.1 & 1.6 & 3.4 & 0.0 \\
\hline $\mathrm{W} 1^{\mathrm{d}}$ & $\mathrm{Be}$ & 6 & 70.2 & 6.63 & 0.33 & 9.9 & 5.8 & 0.2 & 0.1 \\
\hline $\mathrm{W} 2^{\mathrm{f}}$ & $\mathrm{Gg}$ & 10 & 72.4 & 6.90 & 0.47 & 7.5 & 6.2 & 0.1 & 0.0 \\
\hline $\mathrm{W} 3^{\mathrm{f}}$ & $\mathrm{Gg}$ & 4 & 72.4 & 6.59 & 0.42 & 8.1 & 6.0 & 0.3 & 0.1 \\
\hline W4 & $\mathrm{Fu}$ & 12 & 58.7 & 5.54 & 0.26 & 13.0 & 2.3 & 4.9 & 4.5 \\
\hline W5 & $G x$ & 14 & 67.8 & 6.80 & 0.44 & 7.8 & 4.5 & 0.1 & 0.0 \\
\hline W6 & $\mathrm{Ji}$ & 6 & 63.6 & 5.25 & 0.29 & 10.2 & 3.5 & 5.3 & 0.0 \\
\hline W7 & $\mathrm{Ta}$ & 11 & 67.3 & 5.86 & 0.37 & 6.2 & 2.4 & 0.1 & 0.1 \\
\hline W8 & HK & 12 & 70.1 & 6.06 & 0.39 & 8.2 & 4.0 & 0.1 & 0.0 \\
\hline $\mathrm{G} 1^{\mathrm{d}}$ & $\mathrm{Be}$ & 11 & 70.8 & 7.32 & 0.55 & 11.8 & 1.9 & 0.0 & 0.1 \\
\hline $\mathrm{G}^{\mathrm{d}}$ & $\mathrm{Be}$ & 6 & 73.1 & 7.45 & 0.51 & 10.2 & 2.2 & 0.0 & 0.0 \\
\hline G3 & Sh & 9 & 67.8 & 7.08 & 0.59 & 14.2 & 0.5 & 0.0 & 0.1 \\
\hline
\end{tabular}

$\mathrm{R}$ - red sufu; W - white sufu; $\mathrm{G}$ - grey sufu.

${ }^{a}$ Be: Beijing (capital of China), He: Heilongjiang (North-east of China), Ji: Jiangsu (East), Sh: Shanxi (West), Si: Sichuan (South-west), Gg: Guangdong (South), Gx: Guangxi (South), HK: Hong Kong (South), Ta: Taiwan (South-east) and Fu: Fujiang (South-east).

${ }^{\mathrm{b}}$ Age after manufacturing date.

${ }^{\mathrm{c}}$ All analyses on duplicate subsamples.

${ }^{\mathrm{d}}$ Samples from the same manufacturer.

${ }^{\mathrm{e}}$ Samples from the same manufacturer.

${ }^{\mathrm{f}}$ Samples from the same manufacturer. 
Table 2

Microbiological composition of commercial sufu (log CFU/g sample)

\begin{tabular}{|c|c|c|c|c|c|c|c|}
\hline Sample code & TMAB & $\begin{array}{l}\text { Bacterial } \\
\text { endospores }\end{array}$ & THB10 & THB17.5 & LAB & B. cereus & C. perfringens \\
\hline $\mathrm{R} 1$ & 5.7 & 5.9 & 4.5 & 2.1 & $<1$ & 2.5 & 1.3 \\
\hline $\mathrm{R} 2^{\mathrm{d}}$ & 6.0 & 5.7 & 4.3 & 1.8 & $<1$ & 2.7 & $<1$ \\
\hline $\mathrm{R} 3^{\mathrm{d}}$ & 6.2 & 6.6 & 5.1 & 2.3 & $<1$ & 3.4 & $<1$ \\
\hline $\mathrm{R} 4^{\mathrm{d}}$ & 6.6 & 5.7 & 5.6 & 2.6 & $<1$ & 3.7 & 2.6 \\
\hline $\mathrm{R} 5$ & 5.2 & 5.2 & 4.1 & 1.9 & $<1$ & 3.6 & $<1$ \\
\hline $\mathrm{R} 6^{\mathrm{e}}$ & 7.0 & 6.9 & 5.9 & 2.2 & 2.6 & 5.1 & 1.3 \\
\hline $\mathrm{R} 7^{\mathrm{e}}$ & 6.8 & 6.9 & 6.2 & 3.3 & $<1$ & 3.5 & $<1$ \\
\hline $\mathrm{R} 8^{\mathrm{e}}$ & 6.8 & 6.6 & 5.3 & 3.2 & $<1$ & 3.2 & $<1$ \\
\hline R9 & 6.7 & 6.4 & 6.6 & 3.8 & $<1$ & 2.3 & $<1$ \\
\hline $\mathrm{R} 10$ & 6.0 & 5.7 & 5.6 & 3.3 & $<1$ & 2.2 & $<1$ \\
\hline R11 & 7.0 & 7.0 & 5.9 & 3.6 & 2.3 & 5.3 & 5.1 \\
\hline $\mathrm{R} 12$ & 6.9 & 6.7 & 5.1 & 3.1 & $<1$ & 4.6 & $<1$ \\
\hline $\mathrm{W} 1^{\mathrm{d}}$ & 5.6 & 6.0 & 3.3 & 1.7 & 2.6 & 3.6 & 1.3 \\
\hline $\mathrm{W} 2^{\mathrm{f}}$ & 5.3 & 5.4 & 4.7 & 4.4 & 2.7 & 3.4 & $<1$ \\
\hline $\mathrm{W} 3^{\mathrm{f}}$ & 6.0 & 5.9 & 4.9 & 4.6 & 2.6 & 2.7 & $<1$ \\
\hline W4 & 7.8 & 7.8 & 7.0 & 2.7 & 3.7 & 3.5 & $<1$ \\
\hline W5 & 5.5 & 5.4 & 3.5 & 3.6 & 2.2 & 5.0 & $<1$ \\
\hline W6 & 5.1 & 4.9 & 4.0 & 3.9 & 3.5 & 3.6 & 1.6 \\
\hline W7 & 6.9 & 3.8 & 3.6 & 3.7 & 7.7 & 2.4 & $<1$ \\
\hline W8 & 6.0 & 3.2 & 3.8 & 4.0 & 5.9 & 2.2 & $<1$ \\
\hline $\mathrm{G} 1^{\mathrm{d}}$ & 6.6 & 6.2 & 4.1 & 3.7 & 2.8 & 4.3 & $<1$ \\
\hline $\mathrm{G} 2^{\mathrm{d}}$ & 5.8 & 5.7 & 4.1 & 4.0 & 2.6 & 3.9 & 2.6 \\
\hline G3 & 4.7 & 2.8 & 2.9 & 2.8 & 2.2 & 1.3 & $<1$ \\
\hline
\end{tabular}

$\mathrm{R}$ - red sufu; W - white sufu; G - grey sufu; Abbreviations: TMAB: total count of mesophilic aerobic bacteria; THB10: total count of halotolerant bacteria at $10 \% \mathrm{NaCl}$ level; THB17.5: same, at $17.5 \% \mathrm{NaCl}$; LAB: lactic acid bacteria. All analyses on duplicate subsamples.

${ }^{\mathrm{d}}$ Samples from the same manufacturer.

${ }^{\mathrm{e}}$ Samples from the same manufacturer.

${ }^{\mathrm{f}}$ Samples from the same manufacturer.

resistance of Gram-positive bacteria to ethanol and salt is relatively stronger than that of Gram-negative bacteria (Seiler \& Russell, 1991). THB10 and THB17.5 were detected in all samples, and the number of halotolerant bacteria was inversely proportional to the $\mathrm{NaCl}$ concentration in the media except in W7 and W8. Most of the isolates from THB10 grew after having been inoculated onto PCA without $\mathrm{NaCl}$, indicating that these were not obligate halophilic organisms. On the other hand, most isolates transferred from THB17.5 failed to grow on PCA without $\mathrm{NaCl}$, so these could be obligate halophiles. Lactic acid bacteria are found in many fermented foods. All samples of white and grey sufu contained detectable levels of $\mathrm{LAB}$, with considerable levels $\left(\sim 10^{7}\right.$ and $\left.\sim 10^{6} \mathrm{CFU} / \mathrm{g}\right)$ in $\mathrm{W} 7$ and $\mathrm{W} 8$. Interestingly, there were no detectable spoilage phenomena in samples W7 and W8 with $\mathrm{pH} 5.86$ and $\mathrm{pH} 6.06$ that are not unusually low. Acid spoilage of these products by LAB may have been prevented by the lack of fermentable sugars (Table 1). In only 2 out of 12 red sufu samples could low levels $\left(\sim 10^{2} \mathrm{CFU} / \mathrm{g}\right)$ of LAB be detected. The apparent failure of LAB to spoil red sufu could be due to the use of angkak (red kojic rice) (Nout \& Aidoo, 2001) in red sufu dressing. Antimicrobial effects of angkak have been associated with antibiotics such as angkalactone, monascorubrin and rubropunctatin (Nozaki et al., 1991); LAB in sufu may be sensitive to these antibiotics.

Isolates of presumptive LAB on MRS were Grampositive, oxidase and catalase negative, non-sporeforming rod-shaped bacteria. They could grow in both aerobic and anaerobic conditions, produced acid from ribose but no gas from glucose, so they were initially classified as facultative heterofermentative lactobacilli (Wijtzes et al., 1997). Carbohydrate assimilation data indicated that the lactobacilli isolated from sample R6 were most probably $L b$. curvatus and those from samples W7 and W8 Lb. casei.

In all samples, fungi were absent $(<10 \mathrm{CFU} / \mathrm{g})$. This appears to differ from the data of Pao (1994) who reported $10^{2}-10^{6} \mathrm{CFU} / \mathrm{g}$ in sufu. Most likely the fungi, particularly the mould starters do not survive after the pehtze phase, due to the high levels of salt and/or ethanol in the dressing mixtures applied for ageing and storage.

In Table 2 it is shown that $B$. cereus was isolated from all samples. In three samples (R6, R11 and W5) $\geqslant 10^{5}$ $\mathrm{CFU} / \mathrm{g}$ of $B$. cereus were found, indicating a potential 
hazard for consumers. One-third of commercial sufu samples contained less than $10^{3} \mathrm{CFU} / \mathrm{g}$. Some species of bacilli have been associated with incidents of food-borne disease related to consumption of unheated products. The enterotoxins produced by $B$. cereus are responsible for emetic and/or diarrhoea food poisoning (Granum, 1994). The fact that there are strains of B. cereus that may cause food poisoning with an infective dose as low as $10^{3}-10^{4} \mathrm{CFU} / \mathrm{g}$ (Andersson et al., 1995), should be of concern for the sufu industry.

When 58 presumptive B. cereus colonies were checked by the ISO method, 55 strains $(94.8 \%$ of total) were confirmed to be $B$. cereus. Based on carbohydrate assimilation patterns, the remaining three strains $(5.2 \%$ of total) were identified as B. subtilis. This was also the main species found in a number of randomly picked isolates of spore-forming bacteria from sufu samples.

From Table 2, a quarter of the samples contained $C$. perfringens at low levels (log CFU/g <3.0), but sample R11 contained log 5.1 CFU/g. Sample R11 represents a rather unusual style of sufu, covered with fermented Chinese cabbage and packaged in a plastic vacuumpacked bag. Both the ingredients and the anaerobic packaging could have contributed to the comparitively high level of $C$. perfringens. This organism is known to occur frequently in spices and herbs, at levels of $10^{2}-10^{4}$ CFU/g (Labbé, 2000). The dressing mixtures of some sufu products contain spices and/or herbs, which could also contribute to the presence of $C$. perfringens.

Most Enterobacteriaceae do not tolerate elevated salt levels. Whereas they were found at high levels $\left(\sim 10^{7}\right.$ CFU/g) in pehtze (Cao, 2001), they do not survive the salting and ageing steps. As thus expected, no Enterobacteriaceae were detectable in any of the samples, using VRBG agar with or without $2.5 \% \mathrm{NaCl}$. Similar results were observed in an earlier study (Pao, 1994), in which coliforms were not found in the investigated samples. Although Enterobacteriaceae are unlikely survivors of the final stages of the sufu process, their ability to grow and possibly produce endotoxins during the early pehtze making stage might constitute a hazard. Consequently, toxicological studies are required to assess the potential hazard posed by such toxins during sufu production.

$S$. aureus is often associated with human skin. It occurs in commercial tofu (Van Kooij \& De Boer, 1985), and it is likely to be present in sufu as this involves manual operations on tofu. Due to its salt-tolerance, this pathogen might be expected to survive in sufu. However, it was impossible to detect $S$. aureus in the samples tested due to the fact that there were no visible haloes surrounding the suspect colonies. The competitive microflora (mainly bacilli) prevented the formation of such haloes during the incubation of $S$. aureus, which we were able to confirm with artificially contaminated samples (data not shown). Further research is necessary to find a suitable method for enumeration of $S$. aureus in
Table 3

Attributes sampling plans for sufu

\begin{tabular}{llllll}
\hline Organisms & $\begin{array}{l}\text { Plan } \\
\text { class }\end{array}$ & $n$ & $\begin{array}{l}m \\
(\mathrm{CFU} / \mathrm{g})\end{array}$ & $\begin{array}{l}M \\
(\mathrm{CFU} / \mathrm{g})\end{array}$ & $c$ \\
\hline Enterobacteriaceae & 3 & 5 & 10 & $10^{2}$ & 1 \\
B. cereus & 3 & 5 & $10^{3}$ & $10^{4}$ & 1 \\
C. perfringens & 3 & 5 & $10^{2}$ & $10^{3}$ & 1 \\
S. aureus & 3 & 5 & $10^{3}$ & $10^{4}$ & 1 \\
\hline
\end{tabular}

$n$ - the number of samples to be taken from a lot; $m$ - a count which separates good quality from marginal quality and which most test samples should not exceed; $M-$ a count which if exceeded by any of the test samples would lead to rejection of the lot; $c$ - the maximum number of test samples which may fall into the marginally acceptable category before the lot is rejected (Adams \& Moss, 2000).

sufu samples. Qualitative detection tests for staphylococcal enterotoxins in sufu samples showed that some of the grey sufu (sample G3) contained enterotoxin A. Other enterotoxins (B, C, D, and E) were below level of detection.

Although L. monocytogenes is a salt-tolerant pathogen, being able to grow in $10 \% \mathrm{NaCl}$ and to survive in the presence of $30 \% \mathrm{NaCl}$ (Rocourt \& Cossart, 1997), we could not detect the presence of this pathogen using Rapid'L mono Medium in any of the samples.

\subsection{Microbiological guideline using attributes sampling plans}

Presently no microbiological guidelines exist for sufu. Based on the results of our study we suggest the sampling plan (Adams \& Moss, 2000) as shown in Table 3. This does not take into account the previous history of processing and storage of the product, but serves to distinguish potentially rejectable products on the basis of safety criteria. TMAB was not included in the plan as we consider it to have little direct relevance to safety. Instead we focussed on the pathogens that were encountered in some of the commercial sufu, notably $B$. cereus, $C$. perfringens and $S$. aureus. Enterobacteriaceae were included because of their potential of producing endotoxins.

\section{Conclusion}

The microbiological composition of the sufu indicates that its manufacturing processes and recipes prevent survival or growth of fungi and Enterobacteriaceae. On the other hand, high levels of bacterial endospores and concomitant TMAB were observed in a majority of the samples, which indicates either that highly contaminated tofu and/or dressing mixture were used for sufu production, and/or that poor processing practices (e.g., inappropriate handling or unhygienic condition) were 
involved. Considering that no signs of spoilage were observed, it must be assumed that most bacterial endospores are not metabolically active in this product. In view of hygienic safety and to reduce microbiological counts in general, benefit could be expected from using fresh tofu for pehtze making, by using dressing mixtures with low microbiological load and by maximizing process sanitation.

\section{Acknowledgements}

This research was supported by the Graduate School VLAG (Food Technology, Agrobiotechnology, Nutrition and Health Sciences), The Netherlands.

\section{References}

Adams, M. R., \& Moss, M. O. (2000). Controlling the microbiological quality of foods. In M. R. Adams, \& M. O. Moss (Eds.), Food microbiology (2nd ed., pp. 395-438). UK: Royal Society of Chemistry.

Andersson, A., Rönner, U., \& Granum, P. E. (1995). What problem does the food industry have with the spore-forming pathogens Bacillus cereus and Clostridium perfringens? International Journal of Food Microbiology, 28, 145-155.

Ashraf, H.-R., White, M., \& Klubek, B. (1999). Microbiological survey of tofu sold in a rural Illinois county. Journal of Food Protection, 62(9), 1050-1053.

Brewer, M. S. (2000). Traditional preservatives - Sodium chloride. In R. K. Robinson, C. A. Batt, \& P. D. Patel (Eds.), Encyclopedia of food microbiology (pp. 1723-1728). New York: Academic Press.

Cao, C.-F. (2001). Microorganisms involved in sufu production. M.Sc. Thesis, China Agricultural University (in Chinese).

Eisgruber, H., Schalch, B., Sperner, B., \& Stolle, A. (2000). Comparison of four routine methods for the confirmation of Clostridium perfringens in food. International Journal of Food Microbiology, 57, $135-140$.

Granum, P. E. (1994). Bacillus cereus and its toxins. Journal of Applied Bacteriology, 76, S61-S66.

Han, B.-Z., Rombouts, F. M., \& Nout, M. J. R. (2001). A Chinese fermented soybean food. International Journal of Food Microbiology, 65(1/2), 1-9.

Heisick, J. E., Posas-marty, L. I., \& Tatini, S. R. (1995). Enumeration of viable Listeria species and Listeria monocytogenes in food. Journal of Food Protection, 58(7), 733-736.

Hounhouigan, D. J., Nout, M. J. R., Nago, C. M., Houben, J. H., \& Rombouts, F. M. (1993). Characterization and frequency distribution of species of lactic acid bacteria involved in the processing of mawe, a fermented maize dough from Benin. International Journal of Food Microbiology, 18, 279-287.

ISO/DIS 7932 (1993). Microbiology - General guidance for the enumeration of Bacillus cereus - Colony-count technique at $30^{\circ} \mathrm{C}$. International Organisation for Standardisation, Switzerland.

ISO/DIS 6888-2 (1997). Microbiology of food and animal feeding stuffs - Horizontal method for the enumeration of coagulase- positive staphylococci (Staphylococcus aureus and other species) Part 2: Technique without confirmation of colonies. International Organisation for Standardisation, Switzerland.

Labbé, R. G. (2000). Clostridium perfringens. In B. M. Lund, T. C. Baird-Parker, \& G. W. Gould (Eds.), The microbiological safety and quality of food (pp. 1110-1135). Gaithersburg, MD, USA: Aspen Publishers, Inc.

Nout, M. J. R. (1991). Ecology of accelerated natural lactic fermentation of sorghum-based infant food formulas. International Journal of Food Microbiology, 12, 217-224.

Nout, M. J. R., \& Aidoo, K. E. (2001). Asian fungal fermented food. In H. D. Osiewacz (Ed.), The mycota: Vol. X. Industrial applications. Berlin, Heidelberg: Springer-Verlag (pp. 23-47, Chap.2).

Nout, M. J. R., Bakshi, D., \& Sarkar, P. K. (1998). Microbiological safety of kinema, a fermented soya bean food. Food Control, 9(6), 357-362.

Nozaki, H., Date, S., Kondo, H., Kiyohara, H., Takaoka, D., Tada, H., \& Nakayama, M. (1991). Ankalactone a new $\alpha, \beta$-unsaturated $\gamma$-lactone from Monascus anka. Agricultural Biological Chemistry, 55(3), 899-901.

Pao, S.-C. (1989). Spoilage and pathogenic microorganism quality of sufu, Chinese cheese. M.Sc. Thesis, The Ohio State University.

Pao, S.-C. (1994). Halophilic organisms in sufu, Chinese cheese. Ph.D. Thesis, Order Number 9505268, The Ohio State University.

Park, C. E., Akhtar, M., \& Rayman, M. K. (1994). Evaluation of a commercial enzyme immunoassay kit (RIDASCREEN) for detection of staphylococcal enterotoxins A, B, C, D, and E in foods. Applied and Environmental Microbiology, 60(2), 677-681.

Rehberger, T. G., Wilson, L. A., \& Glatz, B. A. (1984). Microbiological quality of commercial tofu. Journal of Food Protection, 47(3), 177-181.

Rocourt, J., \& Cossart, P. (1997). Listeria monocytogenes. In M. P. Doyle, L. R. Beuchat, \& T. J. Montville (Eds.), Food microbiology, fundamentals and frontiers (pp. 337-352). Washington DC, USA: ASM Press.

Samson, R. A., Van Kooij, J. A., \& De Boer, E. (1987). A survey of the microbiological quality of commercial tempeh in The Netherlands. Journal of Food Protection, 50, 92-94.

Seiler, D. A. L., \& Russell, N. J. (1991). Ethanol as a food preservative. In N. J. Russell, \& G. W. Gould (Eds.), Food preservatives (pp. 153-171). New York, USA: AVI.

Steinkraus, K. H. (1996). Chinese sufu. In K. H. Steinkraus (Ed.), Handbook of indigenous fermented foods (pp. 633-641). New York: Marcel Dekker.

Su, Y.-C. (1986). Sufu. In N. R. Reddy, M. D. Pierson, \& D. K. Salunkhe (Eds.), Legume-based fermented foods (pp. 69-83). Boca Raton, FL, USA: CRC Press.

Van Kooij, J. A., \& De Boer, E. (1985). A survey of the microbiological quality of commercial tofu in The Netherlands. International Journal of Food Microbiology, 2, 349-354.

Wang, R.-Z., \& Du, X.-X. (1998). The production of sufu in China (pp. 1-36). Beijing, China: China Light Industry Press (in Chinese).

Wang, H. L., \& Hesseltine, C. W. (1970). Sufu and Lao-Chao. Journal of Agricultural and Food Chemistry, 18(4), 572-575.

White, Jr, J. W. (1979). Spectrophotometric method for hydroxymethylfurfural in honey. Journal of the Association of Official Analytical Chemists, 62, 509-514.

Wijtzes, T., Bruggeman, M. R., Nout, M. J. R., \& Zwietering, M. H. (1997). A computerised system for the identification of lactic acid bacteria. International Journal of Food Microbiology, 38, 65-70. 